\title{
Statskundskab og journalistik - et mage par?
}

\section{AF ERIK ALBAK}

Statskundskab og journalistik har betydeligt, men ofte overset arve- og tankegods til fælles, som gør, at de to fag i både forskningsog undervisningsmæssigt øjemed ikke blot kan have, men allerede faktisk har stor fornøjelse af hinanden - om end der samtidig gør sig forskelle gældende, som kan besværliggøre partnerskabet. Som i ethvert godt fungerede partnerskab skal der imidlertid være forskelle og individualitet, ellers fungerer det ikke.

1. februar 2006 blev Institut for Journalistik ved Syddansk Universitet omdannet til et Center for Journalistik under Institut for Statskundskab samme sted. Det var der styringsmæssigt mange gode grunde til. Men var der også gode faglige grunde til at knytte de to fag journalistik og statskundskab tættere til hinanden?

Umiddelbart ja: Nok beskæftiger journalistik sig i dag med meget andet end politiske nyheder. Desuagtet udgør den politiske nyhedsjournalistik et kernefelt, ja, mange vil hævde kernefeltet, i det journalistiske arbejde. Og den politiske journalistik har samme genstand som statskundskaben: samfundet, politik og magt. Den politiske journalistik har også væsentlige berøringsflader med de øvrige samfundsvidenskaber: økonomi, sociologi og jura. Men netop som disse fag benyttes som hjælpediscipliner i politologiens analyser af magt og politik, benyttes de på samme måde af journalister til samme formål.

Og så dog: En del kunne også tale imod at knytte de to fag sammen. I begge fag er der en række ofte temmelig negative myter 
om modpartens udøvere. Mange politologiske forskere betragter journalister som dumme, overfladiske, sensationshungrige og moralsk anløbne. Mange journalister betragter omvendt forskere som verdensfjerne, jomfrunalske tågehorn, der ikke beskæftiger sig med virkeligheden - og for så vidt de gør: ikke formår at udtrykke sig, så almindelige mennesker kan forstå det.

Påstanden her er, at de to fag har betydeligt, men ofte overset, fælles arve- og tankegods, som gør, at de i både forsknings- og undervisningsmæssigt øjemed ikke blot kan have, men at de faktisk allerede har stor fornøjelse af hinanden, om end der også er forskelle, som kan besværliggøre partnerskabet. Men som i ethvert godt fungerede partnerskab skal der være forskelle og individualitet, ellers fungerer det ikke.

\section{Ligheder}

Ingen avislæser kan være i tvivl om, at der i dag pågår en kulturkamp i Danmark. I al fald i Jyllands-Postens og Berlingske Tidendes debatspalter. Hvem skulle for få år siden have troet, at kulturradikalisme i Danmark skulle gå hen at blive et samlende skældsord for roden til alle fortidens og nutidens politiske onder? Helt så slemt er det vel endnu ikke fat med oplysningstiden, selv om enkelte danske debattører, ikke mindst blandt den sorteste del af den danske præstestand, har set en lige linje fra oplysningstiden over Karl Marx til Sovjetunionens Gulag.

Under alle omstændigheder er samfundsvidenskaberne, herunder statskundskaben, og journalistik i deres egen selvforståelse børn af oplysningstiden. Oplysningstidens overordnede idé var at styrke den menneskelige fornuft for derigennem at frisætte mennesket fra traditionens og sædvanens snærende bånd. Det er fundamentalt set den idé, der har været og fortsat er styrende for såvel statskundskab som journalistik. Begge arbejder, ligesom Poul Nesgaard og Nulle i sin tid gjorde det, „i sandhedens tjeneste".

Grundlaget for mange af de normer, der i dag styrer såvel det samfundsvidenskabelige som det journalistiske arbejde, opstår med fremvæksten af den borgerlige offentlighed og det moderne demokrati. Her blev der skabt et rum, hvor det gennem offentlig 
meningsudveksling er muligt at nå til enighed om, hvilke argumenter der i egentligste forstand er de mest fornuftige. Det er derfor man i demokratiet finder meningsbrydning og argumentation institutionaliseret som ideal, eksempelvis i form af de borgerlige frihedsrettigheder og Folketingets talerstol. Det er derfor, vi har et parlament - et sted hvor man taler. Eller rettere samtaler.

Det var langt hen ad vejen den borgerlige offentligheds normer, der blev styrende for udviklingen af de normer, der senere udvikledes internt i samfundsvidenskaberne og i journalistik. Det skete for samfundsvidenskaberne allerede i løbet af 1800tallet, og normerne cementeredes videre op gennem det 20. århundrede. For journalistikken skete det noget senere. Indtil 1920'erne eksisterede der hverken i Danmark eller i udlandet noget, der mindede om moderne journalistik. Aviserne var basalt set partiaviser - de politiske partiers ukritiske talerør. Det var først med fremvæksten af det, der er blevet kaldt omnibuspressen, dvs. en presse, der forsøger at nå i princippet hele befolkningen, at løsrivelsen fra partimaskinerne skete, og dermed at de moderne journalistiske professionsnormer voksede frem.

Netop fordi de normer, der er vokset frem for henholdsvis godt videnskabeligt og godt journalistisk arbejde, har fælles rod i oplysningstidens tankegods, har de mange lighedspunkter. Paralleliteten i det videnskabelige og det journalistiske arbejde afspejles i engelsk sprogbrug, hvor man taler om både videnskabelig og journalistisk „research“, altså det forhold, at man analytisk, systematisk og metodisk afdækker et givet emne eller en given sag. Desværre kan begrebet research ikke oversættes til et let klingende dansk begreb, der dækker både videnskab og journalistik. Forskning og undersøgelse gælder kun videnskaben. Efterforskning politiet. Og dybdeborende eller undersøgende journalistik kun journalistikken.

Paralleliteten i det politologiske og det journalistiske arbejde viser sig på en række dimensioner:

\section{Metode og databehandling}

Når det drejer sig om metoder til at generere data for henholdsvis den videnskabelige eller den journalistiske publikation trækkes der tydeligvis på samme tankegang i de to fag: 
- Skriftlige kilder. Både statskundskaben og journalistikken benytter sig grundlæggende af de kildekritiske metoder, der udvikledes inden for historievidenskaben: Er der tale om førsteeller andenhånds kilder? Hvilken tillid kan man have til kilderne? Med hvilket formål er kilderne (mødereferater, journaler, indberetninger, dagbøger, statistikker mv.) produceret? Kan aktører have haft særlige motiver til at sige eller skrive, som de gør?

- Mundtlige kilder. Det drejer sig for begge fags vedkommende først og fremmest om det mundtlige interview, hvor de samme normer benyttes for at vurdere kildernes egnethed til at belyse en given sag.

- Deltagerobservation. Om end det ikke sker så ofte, benytter journalister undertiden deltagerobservation på helt samme måde som samfundsforskere gør det. Et af de kendteste eksempler på dette er vel stadig den tyske forfatter og journalist Günter Wallraffs afsløring i 1970'erne og 1980'erne af industriarbejdernes usle arbejdsvilkår og af det journalistiske arbejde på den tyske Springerkoncerns boulevardavis Bild Zeitung. Et nyligt dansk eksempel er afdækningen af omsorgssvigt på omsorgscentret Fælledgården i København.

Ikke alene er der stor parallelitet mellem statskundskab og journalistik, når der drejer sig om metoderne til at generere data. Der er i princippet heller ingen forskelle i de normer, der gælder for den efterfølgende databehandling og -analyse. Men da der er stor forskel på journalisters og politologers primære publikum, henholdsvis den brede offentlighed og politologiske fagfæller, benytter journalister sjældent de mere avancerede analyseteknikker, man finder i statskundskaben, eksempelvis kompliceret statistiske beregninger, af den simple grund, at kun fagfolk umiddelbart kan læse og forstå disse.

\section{Objektivitetet}

Fælles for journalistik og statskundskab er også objektivitetsnormen, altså det forhold, at forskeren såvel som journalisten skal forsøge at afdække virkeligheden objektivt og ikke subjektivt. Det nærmere indhold af denne norm har været og er fortsat omdi- 
skuteret. Mest radikalt har i dansk samfundsvidenskab, herunder statskundskaben, den opfattelse vundet indpas hos især nogle af fagets yngre udøvere, at ikke blot verden, men også videnskaben er en social konstruktion. I følge dette videnskabssyn findes der ingen objektiv virkelighed, der kan afdækkes videnskabeligt, men kun en subjektivt konstrueret virkelighed - som vi som forskere kan gen-konstruere. På samme måde har forestillingen om den objektive journalistiske afdækning af virkeligheden været problematiseret af det, der går under betegnelsen new journalism. Der er tale om en journalistisk tilgang, der benytter en bevidst litterær stil og en udbredt subjektivitet, der skal give læseren en illusion af nærvær. Imidlertid er hverken socialkonstruktivisme eller new journalism dominerende inden for henholdsvis samfundsvidenskab og journalistik.

De færreste vil i dag gøre det synspunkt gældende, at alt, hvad mennesker erfarer, alene er en vilkårlig konstruktion. Tværtimod er der en betydelig grad af intersubjektiv overførbarhed mellem menneskers erfaringer og viden. Netop for at begrænse omfanget af subjektive værdidomme i det videnskabelige og det journalistiske produkt, har de to fag udviklet professionsnormer, der skal medvirke til at øge den intersubjektive overførbarhed. En af måderne, man forsøger at sikre „objektiviteten“ (eller den intersubjektive overførbarhed) på, er ved at gøre data- og kildematerialet tilgængeligt for alle. Det vil sige, at alle, der måtte ønske at vurdere datas og kilders lødig- og egnethed, kan gøre det. Det betyder eksempelvis et forbud mod at benytte anonyme kilder i både statskundskab og journalistik. Hvis man som læser af et videnskabeligt værk eller en journalistisk artikel ikke kender kildens identitet, har man ingen mulighed for at vide, hvordan man skal bedømme vedkommendes udsagn. Det har været en fast norm i både statskundskab og i journalistik, men begge steder har normen været under pres gennem de senere år. Nok mest tydeligt $\mathrm{i}$ journalistikken, hvor afsløringen af en række sager af vægtig samfundsbetydning ikke ville have været mulig uden brug af anonyme kilder, men hvor der måske er tendens til blandt journalister at udvide opfattelsen af, hvad der udgør vægtige samfundsforhold, undertiden endog betydeligt.

En anden norm, der er fælles for de to fag, er, at hverken sam- 
fundsforskeren eller journalisten må lade sine egne værdinormer være styrende for sin analyse og fremstilling. I journalistikken har denne norm kunnet kollidere med kravet om, at en journalistik historie skal have en vinkel. Derfor omformuleres objektivitetsnormen ofte til, at journalistikken skal være afbalanceret og fair, for eksempel i form af, at alle parter i en konflikt skal høres, og deres synspunkter skal gengives korrekt.

\section{Kritisk analyse}

For både journalistik og statskundskab gælder, at fagets udøvere ikke må holde noget for helligt, herunder de givne magtforhold. Tværtom er det begges opgave fordomsfrit åbent at granske ethvert samfundsfænomen med henblik på over for den læge eller den videnskabelige læser at afsløre den kerne af sandhed, der gemmer sig bag fænomenets umiddelbare fremtoning.

\section{Fremstilling}

Den fremstillingsmæssige parallelitet mellem statskundskab og journalistik er mindst, når det drejer sig om den videnskabelige artikel, der gør brug af megen statistik og et formaliseret, matematisk sprog. Men især når det drejer sig om casestudier, der benytter en bredt vifte af meget forskelligartede datatyper, vil den gode videnskabelige fremstilling gøre brug af mange af de litterært-dramaturgiske elementer, der allerede af forfattere som Victor Hugo, Herman Bang og Holger Drachmann introduceredes og som fortsat benyttes i journalistikken for at gøre en reportage nærværende og spændende. Den gode videnskabelige fremstilling, vel at mærke. Dermed også bemærket, at det ikke altid er tilfældet. Tværtom findes der desværre uendelig mange casestudier, der ikke har forstået nødvendigheden af at benytte litterærtdramaturgiske virkemidler, hvis videnskabelig afrapportering skal undgå at blive dræbende kedsommelig.

\section{Forskelle}

Samtidig med, at findes mange lighedspunkter mellem statskundskab og journalistik, gør der sig en række forskelle gældende. De kan dog bedst ses som gradsforskelle snarere end som 
egentlige modsætninger og har fortrinsvis deres udspring i de forskelle, der eksisterer i produktionsvilkårene for henholdsvis det journalistiske og det videnskabelige arbejde.

\section{Tid}

Forskning har som regel et langt perspektiv, både hvad angår forskningens genstand og dens produktionstid. Man kan ofte lave systematiske, longitudinale studier, dvs. studier, der undersøger et fænomen henover en lang årrække. Og forskere har som regel god - undertiden for god tid - til at færdiggøre deres arbejde. Som antydet i begrebet journalistiks franske oprindelse (jour = dag), har journalisten som regel det dagsaktuelle som genstandsfelt, selv om der også findes dybdeborende og undersøgende journalistik, der kan anvende et længere tidsperspektiv. Og som regel er produktionsvilkårene sådan, at en journalistisk historie skal researches og skrives fra dag til dag.

\section{Mængde}

Netop fordi forskningen ikke har samme tidsmæssige begrænsninger som journalistikken, er der i princippet ingen grænser for, hvor mange data og hvor mange kilder der kan medtages og behandles i en forskningspublikation. Til at kunne behandle og fremstille de store mængder data har man eksempelvis statistiske metoder til sin rådighed. Det tidsmæssige pres og den journalistiske artikels begrænsede omfang tilsiger, at der er grænser for, hvor mange data man kan nå at indsamle og behandle, og hvor stort et antal borgere, beslutningstagere eller andre politiske aktører man kan spørge og citere.

\section{Teoretisk styring og kumularitet}

For forskeren er det et krav, at han orienterer sig i den viden, der allerede findes om et givet emne, teoretisk såvel som empirisk, og at han stiller sig på skulderen af denne. For forskeren er et givet emne eller en given sag ikke interessant i sig selv. Det er kun interessant, hvis det kan bidrage til at øge vor viden om et givet felt. Omvendt for journalisten. Her vil sagen i sig selv have interesse, om end journalisten for at belyse den konkrete sag selvfølgelig bruger den viden, man har om sager af lignende art. Sat på spid- 
sen kan man sige, at sagen om statsminister Anders Fogh Rasmussens tidligere pressechef Michael Kristiansens brug af telefon, taxaboner og kreditkort for journalisten vil have interesse i sig selv, fordi det er pressens opgave at undersøge konkret magtmisbrug, mens sagen for forvaltningsforskeren kun har interesse, hvis den generelt kan bidrage til at belyse fænomenet politisk udpegede embedsmænd.

\section{Dramaturgiske placering}

Journalister og medier kan optræde som en af aktørgrupperne i samfundsvidenskabelige arbejder, men da behandles de nøjagtigt som alle andre aktørgrupper i det politiske liv. Det er eksempelvis det, man gør i den samfundsvidenskabelige medieforskning. Journalister tildeler derimod ofte forskere en særlig rolle i deres nyhedshistorie - en ekspertrolle, hvor forskeren optræder som dommer i det spil, journalisten iscenesætter.

\section{Bruger partnerne hinanden?}

Når nu journalistik og statskundskab har samme genstandsfelt: politik og samfund. Og når der nu er stor parallelitet i arbejdsmetoder og ingen uoverstigelige forskelle, måtte det vel være oplagt, om journalister og politologer trækker på hinandens arbejder. Det gør de faktisk også.

\section{Politologerne}

Politologer benytter ofte journalistik som kilde for deres forskning, eksempelvis ved at referere til fremstillingen af et sagsforløb, en udtalelse eller en vurdering, som fremgår af et journalistisk produkt. Det kan man som forsker gøre netop, fordi journalistik og samfundsvidenskab har et metodefællesskab, hvorfor forskeren kan have tillid til den journalistiske fremstilling eller vurdering. For så vidt forskeren ikke har tillid til en konkret sagsfremstilling, vil det skyldes mistillid til den konkrete journalist, på samme måde som at man som forsker ikke altid har tillid til en forskerkollegas arbejde og derfor ikke ønsker at referere dette.

For det andet benytter politologer i vid udstrækning journalister til at få formidlet deres forskningsresultater til et bredere pu- 
blikum end blot fagfæller. Det kan de netop gøre, fordi journalistikken og statskundskaben har samme genstandsfelt. Derfor vil journalister have en helt naturlig interesse i at berette om politologiske forskningsresultater.

\section{Journalisterne}

Selv om samfundsforskerne således gør flittig brug af journalister, er trafikken den modsatte vej betydelig kraftigere: At journalister gør brug af samfundsforskere. Det er et forhold, som for nylig har været genstand for en undersøgelse (Albæk, Christiansen \& Togeby, 2002; Albæk, 2004). Den viste, at der gennem de sidste 40 år er sket en dramatisk og accelererende stigning - en syvdobling - $\mathrm{i}$ antallet af nyhedsartikler i danske aviser, hvori der henvises til forskere.

Stigningen hænger sammen med to andre udviklingstræk. Det ene er, at dagspressen i relativt mindre grad end tidligere bruger forskere som formidlere af egen og andre forskeres viden. I stedet benytter pressen i stigende grad forskere til at kommentere på politiske problemer og andre forhold, hvor dagsordenen sættes andre steder end i forskernes elfenbenstårn.

Det andet udviklingstræk er, at hvor det tidligere var repræsentanter for de „hårde“ videnskaber, der blev mest omtalt i aviserne, er det i dag samfundsforskerne. Det er dem, der flittigst kommenterer på små og store problemer, som genereres uden for universiteterne - de seneste vælgerundersøgelser eller justitsministerens seneste udspil til en revision af strafferammerne for en given forbrydelse.

Flere forhold kan være med til at begrunde, at journalister ofte henvender sig til forskere for at få en kommentar. En gængs forklaring er, at journalister ikke alene rapporterer, men i høj grad også producerer nyheder. I hele det virvar af hændelser, der dagligt sker, foretager journalister en udvælgelse af, hvad de finder nyhedsværdigt, ligesom de bestemmer, hvordan stoffet skal fortolkes. De kriterier, journalister benytter i deres selektions- og fortolkningsproces, er ikke mindst bestemt af, at vore dages nyhedsmedier er underlagt markedslogik. De er til stadighed underlagt konkurrence, hvor deres ejere og annoncører stiller krav om, at nyhedsprodukterne sælger. For at være interessant 
må en nyhedshistorie derfor være i besiddelse af produktionsværdier som drama, aktualitet, en let beskrivelig historie med to klart adskilte sider, konkretisering, personificering, visualisering og korte, fyndige udsagn. Det vil i vid udstrækning være disse produktionsværdier, som dikterer en histories vinkling eller den kontekst, den bringes i.

Imidlertid strider det mod den journalistiske ideologi, nemlig objektivitetsnormen, selvstændigt at producere nyheder, hvorfor journalisten til at bekræfte sin vinkel og konklusion på en nyhedsartikel har behov for „kompensatorisk legitimitet“, dvs. behov for at låne ekspertens autoritet som indehaver af neutral, faktuel viden. Det er et indtryk af samspillet, som er udbredt blandt forskere: At de ofte ringes op af journalister, som ønsker et citat, der bekræfter vinklingen på en artikel. Og alene det. Får journalisten ikke citatet, ringer han blot videre rundt i forskerverdenen, indtil han har fundet det bekræftende citat.

Umiddelbart kunne denne tolkning se ud til at have noget på sig. Når man spørger såvel journalister som forskere, der har henholdsvis skrevet og kommenteret i en nyhedsartikel, er de enige om, at det i mere end 90 pct. af tilfældene var journalisten, der henvendte sig til forskerne i forbindelse med artiklens tilblivelse. Det er altså journalisten, der har brug for forskeren, og ikke omvendt. Og i 50 pct. at tilfældene er både forskere og journalister enige om, at journalisten havde vinklen på artiklen, inden han kontaktede forskeren.

Meget tyder imidlertid på, at andet kan være på spil. Det interessante er sådan set ikke, at journalisten på forhånd har fastlagt sin vinkel på nyhedshistorien i halvdelen af de gange, han kontakter en forsker. Det bør ikke overraske. Journalister udfører et professionelt arbejde, og en del af dette arbejde består i at lægge en vinkel på nyhedsstoffet. Det overraskende er snarere, at vinklen i halvdelen af tilfældene ikke er fastlagt på forhånd. Det må jo betyde, at forskerne i disse tilfælde kan bidrage med et fagligt input til journalistens arbejde og dermed være med til at påvirke dennes vinkling på nyhedshistorien. Det tyder på, at journalister ikke kun kontakter forskere for at få bekræftet en på forhånd fastlagt vinkel på en nyhedshistorie. Snarere kontakter de forskeren for at få et fagligt input til og en fortolkning på deres nyhedsstof. 
Det billede bekræftes, når man ser på journalisternes begrundelse for at henvende sig til forskerne. I alt væsentligt skyldes henvendelsen, at journalisterne har behov for fagligt input fra forskerne til at fortolke og analysere et givet spørgsmål. Kun i 5 procent af tilfældene angiver journalister, at anledningen til henvendelsen er forskerens egne forskningsresultater. I 51 pct. af tilfældene er anledningen, at de ønsker at få en fortolkning af deres nyhedsstof, og i 21 pct. af tilfældene, at de ønsker baggrundsviden. Man kan vel sige, at det typiske billede er, at journalister benytter forskere som sparringspartnere på fortolkningen og vinklingen af deres nyhedsstof.

\section{Et lykkeligt partnerskab?}

Med det fælles idemæssige arvegods og de mange lighedstræk i tilgangen til henholdsvis det politologiske og det journalistiske arbejde burde der kunne eksistere et lykkeligt partnerskab mellem politologer og journalister. Den lige refererede undersøgelse af journalisters brug af især samfundsforskere tyder på, at samspillet er betydelig bedre, end de almindelige fordomme tilsiger. Det betyder imidlertid ikke, at der ikke er problemer.

\section{På forskersiden}

Udviklingen i antallet af journalistiske artikler, hvori der refereres til forskere, bekræfter ikke det billede, journalister ofte tegner af forskerverdenen: At forskere er verdensfjerne, vrangvillige, jomfrunalske og ikke villige til at stille op til interviews.

Det betyder imidlertid ikke, at der ikke undertiden kan være noget om snakken. Der findes vistnok endnu ikke danske undersøgelser af dette spørgsmål, men der er et par på vej. Til gengæld findes der udenlandske. For få år siden gennemførte det canadiske forskningsråd for samfundsvidenskab og humaniora en undersøgelse af humanistiske forskeres villighed til at formidle deres forskning gennem medierne (Cobden, 2004). Det er nedslående læsning. En meget stor del af forskerne havde stærke fordomme om samarbejdet med journalister - ikke mindst blandt dem, der aldrig selv havde været i medierne - og så det aldeles ikke som deres opgave at formidle noget som helst gennem me- 
dierne. Her bør der gøres en stor indsats for at gøre forskere begribeligt, 1) at bred formidling af deres forskning er vigtig, både fordi et velfungerende demokrati afhænger af, at borgerne er så oplyste som muligt, og fordi de borgere, der betaler for forskningen, har et legitimt krav på at kende forskningsresultaterne; 2) at bred formidling ofte foretages bedst af journalister; 3 ) at journalister nu engang må arbejde professionelt på de journalistiske grundvilkår; og 4) at de bør trænes i, hvordan de kan få deres budskab ud i et samarbejde med journalister, skriftligt såvel som mundtligt.

\section{På journalistsiden}

Nu er det omvendt heller ikke sådan, at forskere ikke undertiden kan have noget at have deres fordomme i. Når produktionsvilkårene i medierne tilsiger, at den journalistisk interessante artikel er præget af drama, aktualitet, en let beskrivelig historie med to klart adskilte sider, konkretisering, personificering, visualisering og korte, fyndige udsagn, ja så kan der let opstå konflikt mellem kravene til den gode forskning og kravene til den gode journalistik.

Man kan tage den danske magtudredning som eksempel. Man fornærmer vist ingen forskere ved at sige, at Magtudredningens forsøg på at formidle dens mange resultater - uanset om det var de individuelle forskere eller Magtudredningens forskningsledelse, der gjorde forsøget - generelt ikke var lykkeligt. Det skyldtes i vid udstrækning, at Magtudredningens publikationer ikke svingede med de journalistiske normer for, hvad der udgør den gode historie. Det er muligt, at resultaterne fra forskernes side kunne være vinklet bedre for at leve op til de journalistiske nyhedskriterier. Men der er også grænser for, hvor langt man kan gå, hvilket følgende to eksempler kan illustrere.

Eksempel 1. Magtudredningens slutrapport (Togeby et al., 2003), som samlede udredningens mange forskellige og forskelligartede forskningsresultater til et samlet hele, blev den 30. november 2003 præsenteret på en konference på Christiansborg. Aftenen inden var Politikens chefredaktør, der havde læst rapporten, i Deadline på DR2. Han gengav rapportens hovedbudskab, at det gik forbavsende godt med det danske demokrati, hvis 
man sammenligner med situationen i Danmark for 30 år siden, og hvis man sammenligner med situationen i andre lande. Han sagde også profetisk, at den konklusion ville være en provokation for danske journalister. For en positiv historie er ikke en god historie, det er kun en negativ. Dansk journalistik er blevet en del af den danske bekymringsindustri, for hvem alt kun er gået én vej de sidste 40 år, nemlig ad H. til. Journalistik præges således af den negative opbyggelighed, som Frederik Stjernfelt og Søren Ulrik Thomsen for nylig har taget under behandling (Stjernfelt \& Thomsen, 2005). Seidenfaden fik desværre alt for meget ret. Alle mulige politiske aktører, der havde en egeninteresse i at sværte Magtudredningens resultater eller dens forskningsledelse til, blev givet uendeligt med spalteplads i aviserne, mens forsvarere af Magtudredningen fik deres indlæg sendt tilbage i hovedet. I flere medier blev kritikerne af Magtudredningens slutrapport viet betydelig mere opmærksomhed og plads end slutrapporten selv.

Eksempel 2. Magtudredningens første forskningspublikation var en undersøgelse af den danske elite, som den så ud i 1932, 1963 og 1999 (Christiansen et al, 2001). Forskerne interesserede sig for den generelle udvikling: Hvordan har eliten over tid ændret sig med hensyn til køn, klasse, uddannelse, erhverv mv.? Den journalist, der først fik færten af, at publikationen var på vej, havde imidlertid ikke interesse i denne generelle problemstilling. For ham ville det journalistiske scoop være at konkretisere og personificere dages elite. Han blev ganske enkelt eddikesur, da han ikke kunne få udleveret de individuelle navne på eliten. Så blev det hans historie. Der fik den store overskrift henover Weekendavisens forside: Navneforbud. Og undertitlen: „Magtudredning. Navnene på de 1800 mest indflydelsesrige danskere tilbageholdes i en ny videnskabelig kortlægning af samfundets elite. Beslutningen angribes for et brud med al normal forskningspraksis“ (Weekendavisen 23.-29. marts 2001).

Journalisten allierede sig med „eksperter“, der kunne bekræfte hans vinkel på historien, at det stred mod de videnskabelige normer, at han ikke kunne få udleveret listen med de elitepersoner, der indgik i undersøgelsen. Nu var de to eksperters viden på feltet noget begrænset, da der var tale om to historieprofessorer, der med al ønskelig tydelighed afslørede, at de ikke har forstand på 
samfundsvidenskabelig metode, og som derfor udtalte, at det var brud på al videnskabelig praksis ikke at offentliggøre navne.

Det er man sikkert glade for at høre i lægevidenskaben. Her er det standardpraksis at benytte dobbelt-blinde forsøg. Det vil sige forsøg, hvor både patient og behandlende læge er uvidende om, hvorvidt patienten får udleveret et aktivt præparat eller en kalktablet. Og det kunne da aldrig falde en lægevidenskabelig forsker ind efterfølgende at udlevere navnene på patienterne til en journalist fra Weekendavisen. På samme måde ville det være galimatias for Magtudredningen at offentliggøre navnene på de konkrete personer, det er indgået i eliteundersøgelsens database. Så skulle der have været offentliggjort 3129 navne med køn, alder, bopæl, job, tillidshverv osv. Hvis man trykte dem med allermindst muligt skrift, ville det fylde 150 sider i bogen. Hvem ville udgive en sådan bog? Hvem ville have glæde af at ødelægge øjnene ved at stave sig igennem en telefonbog? (I parentes kan det bemærkes, at ingen af de mange eliteundersøgelser, der er gennemført i verden, og som kan sammenlignes med den danske, har offentliggjort navnene på elitens medlemmer).

\section{Journalistik og politologi: partnere, men med selvstændige identiteter}

De fælles idemæssige rødder og den store parallelitet i genstandsfelt og analytisk tilgang tilsiger, at journalister og politologer burde kunne have megen glæde af gensidigt samarbejde. Trods ovennævnte eksempler på knaster og trods de mange myter om det modsatte tyder meget da også på, det faktisk er tilfældet: Politologer får formidlet deres forskning gennem medierne, og journalister benytter i vidt omfang politologer og andre samfundsforskere som sparringspartnere i deres journalistiske arbejde.

Men begge parter kunne vinde ved et udvidet samarbejde. Samfundsvidenskabelig medie-, herunder journalistikforskning, har været forbløffende begrænset. Der findes en betydelig dansk tradition for medieforskning, men den udføres så godt som udelukkende af humanister. Kun et par danske politologer har haft medier generelt og journalistik specifikt som hovedfokus i deres 
forskning. Det kan undre, når man tænker på, hvor vigtig en politisk institution medierne menes at være i et moderne demokrati. Derfor er der al mulig grund til at opprioritere den samfundsvidenskabelige og her især den politologiske medie- og journalistikforskning. Den forskning, der skal udføres, vil være lige relevant for det journalistiske og det politologiske forsknings- og undervisningsmiljø: Viden om, hvad der betinger den politiske journalistiks indhold og dennes effekt på borgernes og beslutningstagernes holdninger og adfærd. Af samme grund vil journalist- og statskundskabsstuderende med fordel kunne undervises sammen: Det vil kunne øge udbuddet af medierelevante fag, som de studerende kan vælge sig ind på, og det vil kunne berige undervisningen at samundervise studenter med forskellig faglig baggrund.

Det er imidlertid ikke alene, hvad angår de samfundsvidenskabelige mediefag, at det giver god mening med et samarbejde mellem statskundskab og journalistik. For de journaliststuderendes vedkommende gælder, at de ud over at lære noget om, hvordan journalistikken fungerer i et moderne demokrati, og ud over at lære det faglige håndværk at skrue en journalistik historie ordentlig sammen, skal lære noget om, hvordan samfundet fungerer. Det er i dagens samfund ikke tilstrækkeligt at være den klassiske journalist, der indlevende og „nøgen“ er i stand til at sætte sig ind i og videreformidle en hvilken som helst situation det være sig den hjemløses eller statslederens livs- og verdensopfattelse, landmandens frustrationer over tåbelige miljøregler eller sidste udspil fra en velfærdskommission. Dagens journalist skal fortsat kunne springe mellem forskellige emner. Men for i dag at kunne gøre dette, må han være „påklædt“ (Mylenberg, 2006). Ikke så meget hvad angår paratviden. Men mere hvad angår analytiske og vidensbaserede færdigheder til hurtigt og effektivt at kunne sætte sig ind i og kritisk forholde sig til de oplysninger, han stilles overfor. Ellers kommer journalisten alt for let til kort over for de politiske aktører - embedsmænd, partier, organisationer, virksomheder og for den sags skyld: eksperter der kan have en egeninteresse $\mathrm{i}$ at få ham overbevist om deres version af en given historie. Og som i dag ofte besidder kommunikationskompetencer, der overgår journalistens. Netop her kan 
en journalistuddannelse drage fordel af at have samfundsvidenskabelige undervisere under samme tag, der kan opøve de journaliststuderendes analytiske færdigheder og viden om samfundets funktionsmåde. Omvendt skal kandidater i statskundskab i deres fremtidige virke på arbejdsmarkedet ikke længere beskæftige sig alene med sagsbehandling. De skal i allerhøjeste grad kunne kommunikere og være i besiddelse af viden om, hvordan myndigheder, organisationer og virksomheder fungerer i et samspil med medierne. Og her kan en statskundskabsuddannelse drage fordel af at have journalistikundervisere under samme tag, der kan opøve de studerendes færdigheder i at kommunikere klart og effektivt.

Men indebærer det også en risiko at undervise kommende embedsmænd og journalister under samme tag? Ja! Det er uhyre vigtigt, at statskundskab og journalistik bevarer deres selvstændige faglige identitet. Det er to vidt forskellige jobfunktioner, kandidater i henholdsvis journalistik og statskundskab efter endt studieforløb skal varetage. Især for journalisterne vil der kunne være en risiko for, at de mister deres kritiske sans, hvis de kommer til at fraternisere med magthaverne. Det er vigtigt, at de ved, hvordan magthavere tænker og agerer. Men de må ikke komme for tæt på. Ikke mindst i en tid, hvor kommende magthavere undervises i, hvordan journalister tænker og handler, og hvordan man kan kommunikere strategisk, så man sikrer maksimal chance for, at journalisten overtager netop den version af en sag, som man selv ønsker frem. Journalistik og statskundskab er ikke et helt umage par. Men de skal helst ikke stå i et for mage-ligt forhold til hinanden. 


\section{N OTER}

1. Artiklen er en omarbejdning af forfatterens forelæsning i forbindelse med hans tiltrædelse som professor i statskundskab og journalistik ved Syddansk Universitet.

\section{REFEREN CER}

Albæk, Erik (2004). Eksperter kan vare gode nok, men ..., Århus: Aarhus Universitetsforlag.

Albæk, Erik, Peter Munk Christiansen \& Lise Togeby (2002). Eksperter $i$ medierne: Dagspressens brug af forskere 1061-2001, Århus: Aarhus Universitetsforlag.

Christiansen, Peter Munk, Birgit Møller \& Lise Togeby (2001). Den danske elite, Århus: Aarhus Universitetsforlag.

Cobden, Michael (2004). Disseminating Humanities Research Through the Mass Media, Report to the SSHRC, Oct. 25.

Mylenberg, Troels (2006). „Omklædning. Journalister skal klædes bedre på“, Politiken, 13. november.

Sjernfelt, Frederik \& Søren Ulrik Thomsen (2005). Kritik af den negative opbyggelighed, København: Vindrose.

Togeby, Lise, Jørgen Goul Andersen, Peter Munk Christiansen, Torben Beck Jørgensen \& Signild Vallgårda (2003). Magt og demokrati i Danmark: Hovedresultater fra Magtudredningen. Århus: Aarhus Universitetsforlag. 